\title{
Chemical composition and antioxidant activity of extracts from Erythroxylum suberosum A.St. Hil.leaves
}

\author{
Ivelone M. de C. Barros ${ }^{1}$, Bruno H. M. Leite ${ }^{2}$, Caio F. M. Leite ${ }^{2}$, Christopher W. Fagg ${ }^{2}$, Sueli M. Gomes ${ }^{3}$, \\ Inês Sabioni Resck ${ }^{4}$, Yris M. Fonseca-Bazzo ${ }^{1}$, Pérola O. Magalhães ${ }^{1}$, Dâmaris Silveira ${ }^{1 *}$ \\ ${ }^{1}$ Faculdade de Ciências da Saúde, Universidade de Brasília, Campus Universitário Darcy Ribeiro, Asa Norte, Brasília, DF, Brazil. ${ }^{2}$ Faculdade de Ceilândia, \\ Universidade de Brasília, Campus Ceilândia, Centro Metropolitano, conjunto A, lote 01, Brasília, DF, Brazil. ${ }^{3}$ Departamento de Botânica, Instituto de \\ Ciências Biológicas, Universidade de Brasília,Campus Universitário Darcy Ribeiro, Asa Norte, Brasília, DF, Brazil. ${ }^{4}$ Instituto de Química. Universidade de \\ Brasilia, Campus Universitário Darcy Ribeiro, Asa Norte, Brasília, DF, Brazil.
}

\begin{tabular}{l}
\hline ARTICLE INFO \\
\hline Article history: \\
Received on: $12 / 06 / 2016$ \\
Accepted on: $26 / 08 / 2016$ \\
Available online: $30 / 03 / 2017$ \\
\hline Key words: \\
Erythroxylum, phenolic \\
compounds, Cerrado.
\end{tabular}

\begin{abstract}
Erythroxylum suberosum A. St. Hill. has been used as anti-rheumatism, anesthetic and for indigestion in Brazilian folk medicine.The crude extracts from leaves were obtained by maceration or infusion. The extracts showed no toxicity to brine shrimp lethality assay. The total phenolics and flavonoids contents were more significant in aqueous and ethanol extracts than its fractions (dichloromethane and hydro-methanol). The antioxidant potential of the crude aqueous extract was, approximately, 4.5 times higher than BHT, while the ethanol extract was 5.9 times. On the other hand, a hydro-methanol fraction from crude ethanol extract was 7.6 times more potent than BHT. Also, it was described the isolation and structural identification of isoquercitrin, rutin, quercetin and isomers catechin and epicatechin, from leaves of E. Suberosum.
\end{abstract}

\section{INTRODUCTION}

Erythroxylaceae, with its main centres of diversity and endemism in Venezuela, Brazil, and Madagascar, has four genera and approximately 240 species with pan-tropical distribution (Plowman and Hensold, 2004). The genera Aneulophus, Nectaropetalum, and Pinacopodium, have few species with exclusive distribution in Africa (Loiola, et al., 2007). Erythroxylum, on the other hand, is the largest and most representative genus, with about 230 species and wide distribution in the tropical regions of the world (Oliveira, et al., 2011). In Brazil, this genus has about 114 species among the 187 registered to tropical America. Of these, approximately

\footnotetext{
* Corresponding Author

Dâmaris Silveira, Faculdade de Ciências da Saúde, Universidade de Brasília, Campus Universitário Darcy Ribeiro, Asa Norte, Brasília, DF, Brazil.Email:damaris@unb.br
}

74 have restricted distribution, found in the Amazon, Atlantic Forest, and in the dry forests of Cerrado and Caatinga (Loiola, et al., 2007; Plowman and Hensold, 2004). Chemically, the genus is characterized by the presence of tropane alkaloids. Also were also isolated flavonoids, terpenes, and tannins (Ansell, et al., 1993; Barreiros, et al., 2002; Brock, et al., 2005; Chávez, et al., 1996; González-Guevara, et al., 2006; Johnson, et al., 1997; Zuanazzi, et al., 2001). Erythroxylum coca Lamk. and E. novogranatense are the best-known species and studied due to the presence of alkaloids. Cocaine, extracted from the leaves of these species was the first local anaesthetic effective action, but its use in medicine went into decline when it became evident the risks related to its therapeutic use (Grinspoon and Bakalar, 1981; Zuanazzi, et al., 2001). Although this genus is well-represented in the Cerrado and has applications in folk medicine, little is known about the chemical composition and biological activity of most of the species. 
One of them, Erythroxylum suberosum occurs in Cerrado of Central Brazil and is known as fruta-de-pomba, mercúrio do campo and mercureiro (Guarim Neto and Morais, 2003). This plant is used as anti-rheumatism, anesthetic and for indigestion in folk medicine (Barbosa and Pinto, 2003). A preliminary analysis for tropane alkaloids detected traces of cocaine and calystegines (Bieri, et al., 2006; Brock, et al., 2005), and diterpenes were isolated from branches (Nascimento, et al., 2012). In previous work, we had reported the presence of rutin, caffeic acid, catechin and epicatechin at leaves of this species (Elias, et al., 2015; Fonseca, et al., 2014). The hexane, ethanol and aqueous extracts from leaves of E. Suberosum, combined with radiotherapy, were evaluated in human cell lines of oral and hypopharynx carcinomas. The aqueous extract presented the highest activity against oral carcinoma (SCC-9) and hypopharynx (FaDu) strains, associated with radiotherapy in doses of $4 \mathrm{~Gy}$ and $8 \mathrm{~Gy}$, respectively (Elias, et al., 2015; Macedo, et al., 2016). Therefore, the aim of this work is to evaluate the chemical composition of extracts from leaves; the potential cytotoxic properties, by using the Artemia salina model; and the antioxidant activity and contents of total polyphenols and flavonoids.

\section{MATERIAL AND METHODS}

\section{General methods}

The ${ }^{1} \mathrm{H}$ NMR (300 MHz) and ${ }^{13} \mathrm{C}$ NMR (75 MHz) spectra were recorded on Varian Mercury Plus spectrometer (300 MHz, 7.04 T, USA), and TMS was used as an internal standard (Institute of Chemistry - IQ - UnB). Column Chromatography (CC) was performed on silica gel (Kieselgel 60, 70-230 mesh, Merck) and Lipophilic Sephadex ${ }^{\mathrm{TM}}$ LH-20 Sigma-Aldrich (25-100 $\mu \mathrm{m}$ - Sigma-Aldrich BrasilLtda). Thin Layer Chromatography (TLC) was performed in a glass holder with silica gel 60G (Merck) or Kieselgel 60 ALUGRAM SIL G. (Macherey-Nagel). Spots were visualized by spraying revealing anisaldehyde-sulfuric and NP-PEG and ultraviolet (UV). For the determination of antioxidant activity and quantification of phenolic compounds in the samples, the absorption measurements were performed on Shimadzu - UV 1601 spectrophotometer.

\section{Plant material}

Aerial parts of Erythroxylum suberosum were collected at Savannah regions of the Federal District - Brazil in August 2009. A voucher specimen was deposited at the Universidade de Brasília Herbarium (UB) by number Fagg CW 2192. The plant material was dried at oven under a temperature lower than $40{ }^{\circ} \mathrm{C}$, and then the leaves were separated from twigs and crushed with the help of a blender.

\section{Pharmacognostic study}

Pharmacognostic characterization was carried out in extracts from leaves of E. Suberosum by using classical pharmacognostic techniques and reference standards. The objective of this analysis was to detect the presence of phenolic compounds in extracts polar this species. The samples were eluted with a mixture of ethyl acetate, glacial acetic acid, formic acid and water (100:11:11:26) (Wagner, et al., 1984). For spots visualization, NP-PEG and UV (364 nm) were used.

\section{Extraction and isolation}

Dried and powdered leaves of E. Suberosum (669 g) were exhaustively extracted by maceration with $n$-hexane and then ethanol (four times at room temperature). Evaporation of the solvent under reduced pressure $\left(40{ }^{\circ} \mathrm{C}\right)$, gave crude extracts hexane $(\mathrm{EH}, 8.6 \mathrm{~g})$ and ethanol (EE, 65.1 g). The aqueous extract (EAq, $6.2 \mathrm{~g}$ ) was obtained by infusion (129 g) in distilled water (3 L) at $70{ }^{\circ} \mathrm{C}$. The mixture cooled to $40{ }^{\circ} \mathrm{C}$ was filtered and stored at $-20{ }^{\circ} \mathrm{C}$ until lyophilisation process. All extracts were stored at -20 ${ }^{\circ} \mathrm{C}$.

The hexane extract ( $7 \mathrm{~g})$ was fractionated by column chromatography on silica gel (height $22 \mathrm{~cm}$, diameter $4.1 \mathrm{~cm}$ ), eluted with Hexane $\rightarrow$ EtOAc $\rightarrow$ MeOH (9:1 $\rightarrow$ 1:9, v/v) giving 176 fractions $(30 \mathrm{~mL})$, and collected into 38 groups according to TLC analysis. An amorphous solid obtained from fractions eluted with Hexane/EtOAc (9:1) was recrystallized after treatment with EtOH/Ether (1:2) and identified by NMR ${ }^{1} \mathrm{H}$ and ${ }^{13} \mathrm{C}$ analysis as along chain aliphatic ester (Nogueira, 1994; Silverstein, 2000).

The ethanol extract (EE, $5.32 \mathrm{~g}$ ) was chromatographed on silica gel column (height $22 \mathrm{~cm}$, diameter $4.1 \mathrm{~cm}$ ) under the same conditions of hexane extract. The collected 289 fractions (50 $\mathrm{mL})$ were pooled into 40 groups. The fraction $283(450.7 \mathrm{mg})$, taken from the column with EtOAc/MeOH (6:4), was treated with acetone and chloroform (2:1) yielding an amorphous solid (61.2 $\mathrm{mg}$ ) identified as isoquercitrin (1). Additionally, part of EE (13.7 g) was partitioned with $\mathrm{MeOH}$, water, and hexane (1:1:2), respectively. The hydro-methanol fraction (FHM) was subjected to a new partition with dichloromethane (1:1). Hexane (FH, $1.27 \mathrm{~g})$ and dichloromethane (FDIC, $0.29 \mathrm{~g}$ ) fractions were concentrated under reduced pressure. Hydro-methanol fraction was submitted to lyophilization (FHM, $10.7 \mathrm{~g}$ ). Aqueous extract (EAq) was chromatographed on Sephadex LH-20 (height $=17 \mathrm{~cm}$, diameter $=3 \mathrm{~cm}$ ) column eluted with $\mathrm{MeOH}$. A yellow solid (14,3 mg) was isolated from fractions 25-27 and identified mostly as rutin (2).

\section{HPLC apparatus and conditions}

The crude extracts and fractions were analyzed as previously described (Fonseca, et al., 2014). LaChrom Elite HPLC system (Hitachi, Tokyo, Japan) liquid chromatograph was used, equipped with L2130 pump, L2200 autosampler; L2300 column oven adjusted at $25^{\circ} \mathrm{C}$ and L2455 DAD detector (Hitachi, Tokyo, Japan). The detector was set at $280 \mathrm{~nm}$ and $354 \mathrm{~nm}$. Separation was performed on Purospher Star reverse phase C18e column (5 $\mu \mathrm{m}, 150 \mathrm{~mm} \times 4.6 \mathrm{~mm}$ i.d.) in combination with an appropriate guard column (4 x 4; $5 \mu \mathrm{m}$ particle size)(Merck, Germany). The solvents were aqueous phosphoric acid (1\%) (solvent A) and acetonitrile (solvent B), employing the following elution gradient: $90 \% \mathrm{~A}$ and $10 \% \mathrm{~B}$ for $0 \mathrm{~min}, 70 \% \mathrm{~A}$ and $30 \% \mathrm{~B}$ for $40 \mathrm{~min}, 50 \%$ $\mathrm{A}$ and $50 \% \mathrm{~B}$ for $50 \mathrm{~min}, 90 \% \mathrm{~A}$ and $10 \% \mathrm{~B}$ for $55 \mathrm{~min}$, at a flow 
rate of $0.6 \mathrm{~mL} / \mathrm{min}$. The compounds present in the samples were characterized according to their UV-vis spectra and identified by their retention times in comparison with standards. Before the determination by HPLC, the samples were solubilized in methanol or water $(2 \mathrm{mg} / \mathrm{mL})$ and filtered. All standard compounds were prepared in methanol $(1 \mathrm{mg} / \mathrm{mL})$ just before use. Data acquisition was performed using EZChrom Elite software (version 3.3.2 SP1 (Scientific Software. Inc.).

\section{Antioxidant activity (Phosphomolybdenium complex assay)}

The total antioxidant capacity was evaluated by Prieto's method (Prieto, et al., 1999) with adaptations. The test is based on the reduction of $\mathrm{Mo}(\mathrm{VI})$ to $\mathrm{Mo}(\mathrm{V})$ by the extract that promote a green phosphate/Mo(V) complex formation at acid medium. An aliquot of $200 \mu \mathrm{L}$ of extract solution $(1000 \mu \mathrm{g} / \mathrm{mL})$ in ethanol was combined with two $\mathrm{mL}$ of reagent solution ( $0.6 \mathrm{M}$ sulfuric acid, 28 $\mathrm{mM}$ sodium phosphate, and four $\mathrm{mM}$ ammonium molybdate). The flasks were incubated at $95^{\circ} \mathrm{C}$ for $90 \mathrm{~min}$. The mixture was cooled to room temperature; the absorbance of the solution was measured at $695 \mathrm{~nm}$ against a blank. The blank solution $(1 \mathrm{~mL}$ of reagent solution plus the same volume of the solvent used for the sample) was incubated under the same conditions as the rest of the samples. This method is quantitative and expresses antioxidant activity as the number of the equivalent of standard compound. Ascorbic acid, butylhydroxytoluene (BHT) and quercetin were used as reference substances (positive controls). The experiment was carried out in triplicate.

\section{Brine shrimp lethality test (BST)}

Crude extract and fractions were tested for brine shrimp toxicity model. The assay was performed according to the simplified Meyer's method (Meyer, et al., 1982). Brine shrimp Artemia salina L. encysted eggs (Maramar) were incubated in artificial seawater at $28^{\circ} \mathrm{C}$ with vigorous aeration, under a continuous light regime. Samples were dissolved in DMSO (200 $\mu \mathrm{L})$ and $20 \mathrm{~mL}$ of artificial sea water. Serial dilutions were prepared in the same solution. Approximately $48 \mathrm{~h}$ after hatching, ten metanauplii was added to each set of tubes containing samples with different concentration $(500 \mu \mathrm{g} / \mathrm{mL}, 250 \mu \mathrm{g} / \mathrm{mL}$ and 125 $\mu \mathrm{g} / \mathrm{mL})$ and further incubated with sufficient light and aeration for 24h. A control containing DMSO was included in each set of experiments. Potassium dichromate $\left(\mathrm{LD}_{50}=20 \mu \mathrm{g} / \mathrm{mL}\right)$ was used as reference (Perfeito, et al., 2005). Probit analysis calculated LC50 (after 24h). The experiment was carried all in triplicates.

\section{Total phenolic contents (TPC)}

This assay was performed using the Folin-Ciocalteau colorimetric method with modifications (Kumazawa, et al., 2004). Briefly, $65 \mu \mathrm{L}$ of methanol solution from crude extract and fractions in the concentration of $2 \mathrm{mg} / \mathrm{mL}$ were mixed with $250 \mu \mathrm{L}$ $\mathrm{Na}_{2} \mathrm{CO}_{3} \quad 10 \%$ and $250 \mu \mathrm{L}$ Folin-Ciocalteau reagent (SigmaAldrich), and the volume was completed for $2500 \mu \mathrm{L}$ with distilled water. The absorbance was measured in aspectrophotometer (Shimadzu UV-1601) at $700 \mathrm{~nm}$ after $1 \mathrm{~h}$ incubation at room temperature. The samples were evaluated at the final concentration of $52 \mu \mathrm{g} / \mathrm{mL}$. The total phenolic contents were expressed as gallic acid equivalents $(\mu \mathrm{g} / \mathrm{mg})$ from the calibration curve. All samples were analyzed in triplicates.

\section{Total flavonoid contents}

Total flavonoid contents in crude extract and fractions were determined according to the method of Woisky and Salatino (1998), with modifications (Buriol, et al., 2009; Woisky and Salatino, 1998). To $250 \mu \mathrm{L}$ of sample solutions at a concentration of $2000 \mu \mathrm{g} / \mathrm{mL}$ in methanol, $125 \mu \mathrm{L} \mathrm{AlCl}_{3} 5 \%$ methanol solution was added, and the volume was completed for $2500 \mu \mathrm{L}$ with distilled water and mixed. The absorbance was measured after $1 \mathrm{~h}$, in a spectrophotometer (Shimadzu UV-1601) at $425 \mathrm{~nm}$. The samples were evaluated at the final concentration $200 \mu \mathrm{g} / \mathrm{mL}$. Total flavonoid content was calculated as quercetin equivalent $(\mu \mathrm{g} / \mathrm{mg}$ ) from the calibration curve. All samples were analyzed in triplicates.

\section{RESULTS AND DISCUSSION}

\section{Pharmacognostic study}

The preliminary qualitative evaluation by TLC on silica gel revealed the presence of caffeic and chlorogenic acids, as well as and rutin in ethanol and aqueous extracts, by comparison with the standards Chlorogenic acid (Sigma), Caffeic acid (Sigma) and Rutin (authentic sample), under the same conditions. The obtained results indicated the absence of alkaloids in the analysed samples.

\section{HPLC-DAD analysis}

By the comparison of UV spectra and retention time of the sample with standards, it was possible to identify some phenolics compounds in extracts and fractions from leaves of $E$. Suberosum. The samples showed a large number of compounds and good similarity between the chromatographic profiles (Figure 1). Most of the peaks showed two maximum absorptions, which fell within the ranges of 255-279 $\mathrm{nm}$ and 353-369 $\mathrm{nm}$, characteristic of aromatic rings of flavonoids and flavones (Luo, et al., 2011) (Table 1). Peaks of 1, 2, 4 and 5 had catechin characteristic UV/Vis spectra, with maximum absorbance at 281 $\mathrm{nm}$, and no absorption at 330 or $350 \mathrm{~nm}$ (Figure 1). It was possible to identify the glycoside flavonoid rutin (1) (peak 3 and 6) in the composition of ethanolic (EE) and aqueous (EAq) extracts, in addition to catechin derivatives. Also,it was observed the presence of the flavonoids isoquercitrin (2) (peak 7 and 9) and quercetin (3) (peak 8) in dichloromethane (FDIC) and hydromethanolic (FHM) fractions. Standards confirmed the characteristic UV/Vis spectra of found catechins and flavonols. Moreover, these results corroborate with described by Arapitsas (2008) that showed the typical UV/Vis spectra of catechins and flavonoids (Arapitsas, 2008). It was possible to identify the following compounds: rutin (1), isoquercitrin (2), quercetin (3) catechin (4), and epicatechin (5), by comparison with commercial standards (Figure 1). The findings were corroborated by NMR data. 
Table 1: Chromatographic and spectroscopic data of Erythroxylumsuberosum A. St. Hill. leaves extracts.

\begin{tabular}{|c|c|c|c|c|c|}
\hline \multirow{2}{*}{ Phenolic compounds } & \multicolumn{4}{|c|}{ Plant extracts $\left[\mathbf{R}_{\mathrm{t}}(\min ),. \lambda_{\max }(\mathrm{nm})\right]$} & \multirow{2}{*}{ Standard } \\
\hline & $\mathbf{E E}$ & FHM & FDIC & EAq & \\
\hline Quercetin & - & - & Peak 8 47.17, 255/369 & -1 & $46.8,255 / 370$ \\
\hline Rutin & Peak 3 27.12, 255/353 & - & - & Peak $626.99,256 / 353$ & $27.08,256 / 355$ \\
\hline Isoquercitrin & - & Peak $928.43,255 / 354$ & Peak $728.43,256 / 354$ & - & $28.88,257 / 357$ \\
\hline (+)-catechin hydrated & Peak 1 14.1, 281 & - & - & Peak 4 14.1, 281 & $14.1,279$ \\
\hline (-)-epicatechin & Peak 2 18.7, 278 & - & - & Peak 5 18.7, 278 & $18.7,279$ \\
\hline
\end{tabular}

$\mathrm{EAq}=$ aqueous extract $\mathrm{EE}=$ ethanol extract; FDIC = dichloromethane fraction; FHM= hydromethanol fraction.<smiles>O=c1c(O)c(-c2ccc(O)c(O)c2)oc2cc(O)cc(O)c12</smiles>

$$
\begin{array}{ll}
\mathbf{1} \text { rutin } & \multicolumn{1}{c}{\text { rutinoside }} \\
\mathbf{2} \text { isoquercitrin } & \text { glucose } \\
\mathbf{3} \text { quercetin } & \mathrm{H}
\end{array}
$$

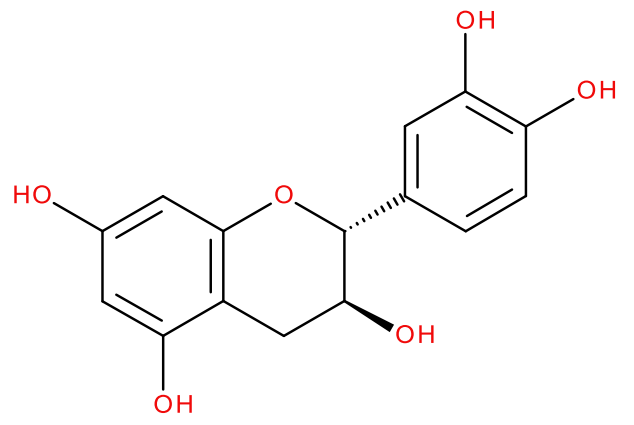

4 catechin

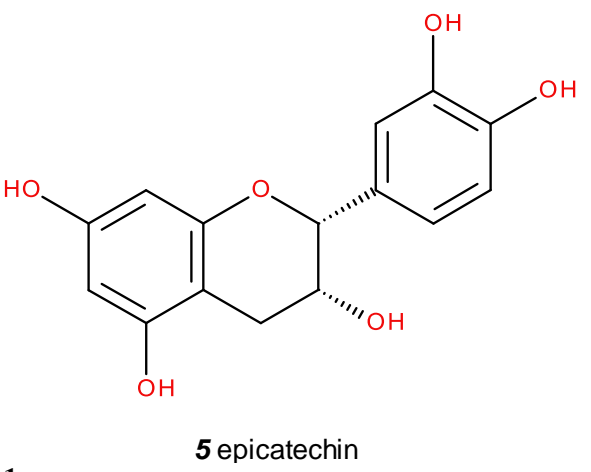

Figure 1

\section{Isolation and identification of the constituents}

The fractionation of the hexane extract $(\mathrm{EH})$ of $E$. Suberosum leaves led to the isolation and structural identification of a mixture of long chain aliphatic esters by ${ }^{1} \mathrm{H}$ and ${ }^{13} \mathrm{C}$ NMR and comparison with literature data (Wang, et al., 2010). Compound 1 was isolated from the aqueous extract by repeated $\mathrm{CC}$ on Sephadex LH-20 and analyzed by TLC and NMR techniques. $1 \mathrm{H}$ and ${ }^{13} \mathrm{C}$-NMR shifts of $\mathbf{1}$ were in excellent correspondence to those reported for rutin (Fonseca, et al., 2007; Krenna, et al., 2003).

Compound 2 was isolated from crude ethanol extract (EE) and comparison of the $\mathrm{R} f$-TLC those from authentic substances. NMR analysis led to the identification of $\mathbf{2}$ as isoquercitrin. The ${ }^{1} \mathrm{H}$ NMR spectrum showed characteristic signals for flavonol (a pair of doublet at $\Delta 6.39$ and $\Delta 6.2, J=2.0 \mathrm{~Hz}$, for $6-\mathrm{H}$ and $8-\mathrm{H}$ ), as well as signals assigned 3',4'-dihydroxylation for ring B (a doublet at $\Delta 7.84, J=2.1 \mathrm{~Hz}$ for $2 '-\mathrm{H}$, a double doublet at $\Delta 7.58, J=8.7$ and $2.4 \mathrm{~Hz}$ for $6^{\prime}-\mathrm{H}$, a doublet at $\Delta 6.86, J=8.4 \mathrm{~Hz}$ for $\left.{ }^{\prime}{ }^{\prime}-\mathrm{H}\right)$.Also, one anomeric proton was observed, resonating at $\Delta 5.17$ as a doublet $(J=7.8 \mathrm{~Hz})$ that was confirmed by ${ }^{13} \mathrm{C} \mathrm{NMR}$, with the signal at $\Delta 105.3$, assigned to the sugar carbon linked to aglycone moiety. The signal at $\Delta 61.9 \mathrm{ppm}$ was assigned to C-6" in free form, indicating the presence of only one molecule linked to sugar as reported in the literature (Silva, et al., 2005).

These data suggested that 2 was composed of quercetin as genin with 3-O-glycosidic linkage of the sugar residue confirmed by comparison with those of rutin (Fonseca, et al., 2007; Krenna, et al., 2003), and isoquercitrin (Lee, et al., 2004; Nhiem, et al., 2009).

Rutin (1): ${ }^{1} \mathrm{H}$ NMR $\left(300 \mathrm{MHz}, \mathrm{CD}_{3} \mathrm{OD}\right) \delta 1.1(\mathrm{~d}, J=6.3$ $\mathrm{Hz}), \delta 4.5(\mathrm{sl}), \delta 5.1(\mathrm{~d}, J=7.5 \mathrm{~Hz}), \delta 6.2(\mathrm{~d}, J=1.8 \mathrm{~Hz}), \delta 6.4(\mathrm{~d}, J$ $=2.4 \mathrm{~Hz}), \delta 6.87(\mathrm{~d}, J=8.4 \mathrm{~Hz}), \delta 7.63(\mathrm{dd}, J=8.4$ and $2.1 \mathrm{~Hz})$, $\delta 7.66(\mathrm{~d}, j=1.8 \mathrm{~Hz}) .{ }^{13} \mathrm{C}$ NMR $(75 \mathrm{MHz}, \mathrm{CD} 3 \mathrm{OD}): \delta 17.9$ (C6','), $\delta 68.5$ (C-5','), $\delta 69.7$ (C-6'), $\delta 71.3$ (C-4'”), $\delta 72.1$ (C-2” and 2','), $\delta 73.9$ (C-5”), $\delta 75.7$ ((C-4"'), 877.1 (C-3"), $\delta 78.1$ (C-3"'), $\delta 94.8$ (C-6), $\delta 99.9$ (C-8), $\delta 102.4$ (C-1”), $\delta 104.7$ (C-10), $\delta 105.5$ (C1"'), $\delta 116.5$ (C-5'), $\delta 117.6$ (C-2'), $\delta 123.0$ (C-1'), $\delta 123.5$ (C-6'), $\delta 135.5$ (C-3), $\delta 145.8$ (C-3'), $\delta 149.8$ (C-4'), $\delta 158.5$ (C-2), $\delta 159.5$ (C-9), $\delta 163.0$ (C-5), $\delta 166.0$ (C-7), $\delta 179.3$ (C-4). 
Isoquercitrin (2): ${ }^{1} \mathrm{H}$ NMR $\left(300 \mathrm{MHz}, \mathrm{CD}_{3} \mathrm{OD}\right) \delta 5.17$ $(\mathrm{d}, J=7.8 \mathrm{~Hz}), \delta 6.2(\mathrm{~d}, J=2.0 \mathrm{~Hz}), \delta 6.39(\mathrm{~d}, J=2.0 \mathrm{~Hz}), \delta 6.86($ $\mathrm{d}, J=8.4 \mathrm{~Hz}), \delta 7.58(\mathrm{dd}, J=8.7$ and $2.4 \mathrm{~Hz}), \delta 7.84(\mathrm{~d}, j=2.1$ $\mathrm{Hz}) .{ }^{13} \mathrm{C}$ NMR (75 MHz, CD $\left.3 \mathrm{OD}\right): \delta 61.9$ (C-6"), $\delta 70.0$ (C-4"), $\delta 75.0$ (C-2"), $\delta 77.1$ (C-5"and 3"), $\delta 94.7$ (C-8), $\delta 99.8$ (C-6), $\delta 105.3$ (C-1' and 10), $\delta 116.1$ (C- 2'), $\delta 117.7$ (C- 5'), $\delta 122.9$ (C- 1' and 6'), $\delta 135.7$ (C-3), $\delta 145.8$ (C-3'), $\delta 149.9$ (C-4'), $\delta 158.4$ (C-2), $\delta 158.7$ (C-9), $\delta 162.9$ (C-5), $\delta 166.0$ (C-7), $\delta 179.5$ (C-4).

\section{Brine Shrimp Lethality Test}

Brine shrimp toxicity assay has been considered as a useful probe for preliminary assessment of toxicity and presents a correlation with an in vivo oral acute toxicity model (Parra, et al., 2001). The method is reliable, rapid and has been used for over 30 years in toxicological studies (Subhadra, et al., 2011). It consists of exposing larvae to test sample in saline solution, and lethality is evaluated after $24 \mathrm{~h}$. Lethality assay has been used successfully to bioguide the isolation of cytotoxic (Siqueira, et al., 1998), antimalarial (Perez, et al., 1997), and insecticidal (Oberlies, et al., 1998) compounds from plant extracts. Also, this test has been used as a model to evaluate compounds for their ability to protect against superoxide-mediated toxicity (Matthews, 1995).For toxicity evaluation of plant extracts by brine shrimp bioassay, an $\mathrm{LD}_{50}$ value lower than $1 \mathrm{mg} / \mathrm{mL}$ is considered active (Meyer, et al., 1982).Therefore, to verify the toxicity of crude extracts from aerial parts of E. Suberosum, the ability to induce Artemia salina death was evaluated. The obtained results from microcrustaceans assay showed that none of the tested extracts exhibited toxicity until concentration $5 \mu \mathrm{g} / \mathrm{mL}$, the highest concentration tested in this study. These results are in accordance with Nascimento et al (2012), which found no toxicity for leaves extracts, although branches had presented considerable toxicity to Artemia salina larvae (Nascimento, et al., 2012).

\section{Estimation of total phenolic and flavonoids contents}

Table 2 shows the contents of total phenolic and flavonoid of crude extracts and fractions of E. Suberosum leaves. Phenolic compounds undergo a complex redox reaction with phosphotungstic and phosphomolybdic acids present in the FolinCiocalteu reagent to tungsten and molybdenum oxide in the basic media and subsequent formation of a blue color product (Kumazawa, et al., 2004). All analysed extracts and fractions had a high content of polyphenols with emphasis on the aqueous extract (346.3 $\mu \mathrm{g} / \mathrm{mg}$ sample) and fraction hydro-methanol (FHM) of ethanol extract ( $387.9 \mu \mathrm{g} / \mathrm{mg}$ sample).

The polyphenols content of ethanol extract (EE) (248.77 $\mu \mathrm{g} / \mathrm{mg}$ ) differs to the values obtained by Ribeiro et al. (2016), which found $575.50 \mu \mathrm{g} / \mathrm{mg}$ to ethanol extract of E. Suberosum leaves (Ribeiro, et al., 2015). However, it can be due to the seasonal or extraction methods differences.

The total flavonoid contents were measured spectrophotometrically after complexation with aluminum chloride at $425 \mathrm{~nm}$. The results showed high levels of flavonoids forthe ethanol (EE, $35.3 \mu \mathrm{g} / \mathrm{mg}$ sample) and aqueous (EAq, $32.6 \mu \mathrm{g} / \mathrm{mg}$ sample) extracts and a considerable concentration was observed in the hydro-methanol fraction (FHM, $87.0 \mu \mathrm{g} / \mathrm{mg}$ sample).

Table 2: Total phenolic and flavonoid content of crude extracts and fractions of Erythroxylum suberosum A. St. Hill. leaves.

\begin{tabular}{|c|c|c|c|}
\hline Sample & $\begin{array}{c}\text { Total phenolic } \\
\text { content }(\mu \mathrm{g} / \mathrm{mg} \\
\text { sample })^{a}\end{array}$ & $\begin{array}{c}\text { Total flavonoid } \\
\text { content }(\mu \mathrm{g} / \mathrm{mg} \\
\text { sample })^{a}\end{array}$ & $\begin{array}{c}\text { Extract and } \\
\text { fractions yield } \\
(\%,(\mathbf{w} / \mathbf{w})\end{array}$ \\
\hline EAq & $346.3 \pm 0.04$ & $32.62 \pm 0.006$ & $5^{*}$ \\
\hline $\mathrm{EE}$ & $248.77 \pm 0.04$ & $35.32 \pm 0.01$ & $17.1^{*}$ \\
\hline FDIC & $166.79 \pm 0.01$ & $55.8 \pm 0.004$ & $0.4^{* *}$ \\
\hline FHM & $387.93 \pm 0.06$ & $87.02 \pm 0.001$ & $66.1 * *$ \\
\hline
\end{tabular}

${ }^{a}$ Data expressed as the mean \pm SD $(n=3) ; *$ yield refers to plant material; ** yield refers to crude extract; Total phenolic content and flavonoids are expressed as $\mu \mathrm{g}$ of gallic acid and $\mu \mathrm{g}$ of quercetin equivalents per $\mathrm{mg}$ of sample, respectively. $\mathrm{EAq}=$ aqueous extract $; \mathrm{EE}=$ ethanol extract $\mathrm{FDIC}=$ dichloromethane fraction; FHM= hydromethanol fraction

\section{Determination of antioxidant activity}

The analysis was conducted by the phosphomolybdenum method (Prieto, et al., 1999), and total antioxidant capacity of $E$. Suberosum leaves extracts was expressed as the number of equivalents of ascorbic acid, quercetin and BHT (Table 2). The results showed that all tested samples were quantitatively more efficient in reducing $\mathrm{Mo}(\mathrm{VI})$ to $\mathrm{Mo}(\mathrm{V})$ when compared to the positive control BHT. However, after the partition of the ethanol extract antioxidant activity was higher in the hydro-methanol fraction, which seven times most active than BHT, followed by ethanol and aqueous extracts. This result shows that the antioxidant activity of extracts and fractions of E. Suberosum leaves is consistent with the total phenolic concentration for the same. Phenolic compounds comprise one of the largest and most ubiquitous group of plant metabolites and fall into several categories such as phenolic acids, flavonoids, coumarins, stilbenes, tannins, lignans and lignins (Yang, et al., 2001). Its benefits to human health and nutrition have been recognized. Several activities appear to be related to the action of these compounds including antioxidant, anti-apoptosis, anti-aging, anti-carcinogen (Han, et al., 2007) and have been highly considered for their significant dietary roles as antioxidant and chemoprotective agents (Bravo, 1998). This chemical study showed that E. Suberosum contains rutin, isoquercitrin and quercetin and also catechin derivatives. These compounds present activities widely reported in the literature as antioxidants, anti-inflammatory and other. Thus, the antioxidant properties exhibited by extracts E. Suberosum and fractions are due at least in part to the presence of these compounds known to be bioactive compounds and free radical scavenging. The absence of alkaloids in branches of this species was previously reported (Nascimento, et al., 2012).

The observed characteristic UV/Vis spectra of catechins and flavonols by HPLC analysis were confirmed by standards and comparison with literature data (Arapitsas, 2008). It was possible to identifycatechin, epicatechin, rutin, isoquercitrin and quercetin by comparison with commercial standards (Figure 1). Antioxidants are compounds that inhibit oxidizing chain reactions and can stabilize and deactivate free radicals before they attack their biological targets(Sousa, et al., 2007; Velioglu, et al., 1998). 
Compounds are among the secondary metabolites with antioxidant activity often isolated in several plant species. Flavonoids are the largest class of phenolic compounds with over 8000 compounds known (Pietta, 2000; Yang, et al., 2001).Occur in plants as glycosylated derivatives with cleavage of the free polyphenol taking place possibly in the gastrointestinal tract.

The chemical structure of these compounds with phenolic hydroxyl groups attached to ring conferring the antioxidant activity (Pietta, 2000; Rice-Evans, et al., 1996). Currently, there are papers published on the in vitro antioxidant activity of flavonoids and a correlation between the antioxidant capacity and chemical structure (Wolfe and Liu, 2008). Ahn et al. (2009) found that the anti-angiogenic action of various components of propolis, such as caffeic acid phenyl ester, kaempferol, and quercetin, is correlated with antioxidant capacity of the same (Ahn, et al., 2009). That way, extracts of $E$. Suberosum could be useful in the treatment and even prevention of diseases related to oxidative stress. The involvement of free radicals in the aging process and degenerative diseases associated with aging such as cancer, cardiovascular disease, cataracts, immune system decayed, and brain dysfunction has been observed every day.

Brine shrimp toxicity assay has been considered as a useful probe for preliminary assessment of toxicity as well as oxidant activity of crude plant extracts and fractions (Matthews, 1995). The method is rapid, reliable and has been used for over 30 years in toxicological studies (Subhadra, et al., 2011). It consists of exposing larvae to test sample in saline solution, and lethality is evaluated after $24 \mathrm{~h}$. Lethality assay has been used successfully to assess compounds presenting cytotoxic (Siqueira, et al., 1998), antimalarial (Perez, et al., 1997), and insecticidal (Oberlies, et al., 1998) activities from plant extracts. In the toxicity evaluation of plant extracts by brine shrimp bioassay, an $\mathrm{LD}_{50}$ value lower than $1 \mathrm{mg} / \mathrm{mL}$ is considered active (Meyer, et al., 1982). Based on this premise, the evaluated extracts did not present toxicity.

\section{CONCLUSIONS}

This chemical study showed that E. Suberosum contains rutin, isoquercitrin and quercetin and also catechin derivatives. These compounds present activities widely reported in the literature as antioxidant, anti-inflammatory and other. Thus, the antioxidant properties exhibited by extracts E. Suberosum and fractions are due at least in part to the presence of these compounds known to be bioactive compounds and free radical scavenging. Considering the benefits of phenolic compounds for the health, protecting against degenerative and pathological processes, the results presented in this paper is a contribution to the chemical and biological of E. Suberosum and encourage the continuation of studies with complementary tests.

\section{ACKNOWLEDGEMENTS}

Authors would like to thanks to Fundação de Apoio a Pesquisa do Distrito Federal (FAP-DF), Coordenação de
Aperfeiçoamento Pessoal de Nivel Superior (CAPES), Conselho Nacional de Pesquisa (CNPq), Fundação de Empreendimentos Científicos e Tecnológicos (FINATEC) and Decanato de PósGraduação e Pesquisa (DPP-UnB) for financial support.

Conflict of Interests: There are no conflicts of interest.

\section{REFERENCES}

Ahn MR, Kunimasa K, Kumazawa S, Nakayama T, Kaji K, Uto $\mathrm{Y}$, Hori $\mathrm{H}$, Nagasawa $\mathrm{H}$, Ohta $\mathrm{T}$. Correlation between antiangiogenic activity and antioxidant activity of various components from propolis. Mol. Nutr. Food Res., 2009; 53(5):643-651.

Ansell SM, Pegel KH, Taylor DAH. Diterpenes from the timber of Erythroxylum pictum. Phytochemistry, 1993; 32(4):945-952.

Arapitsas P. Identification and quantification of polyphenolic compounds from okra seeds and skins. Food Chem., 2008; 110(4):10411045 .

Barbosa WLR, Pinto LN. Documentação e valorização da fitoterapia tradicional Kayapó nas aldeias A'Ukre e Pykanu-sudeste do Pará. Braz. J. Pharmacog. , 2003; 13(1):47-49.

Barreiros ML, M. DJ, Pereira PAP, Guedes MLS, David JP. Fatty Acid Esters of Triterpenes from Erythroxylum passerinum. J. Braz. Chem. Soc., 2002; 13(5):669-673.

Bieri S, Brachet A, Veuthey JL, Christen P. Cocaine distribution in wild Erythroxylum species. J. Ethnopharmacol., 2006; 103(3):439-447.

Bravo L. Polyphenols: chemistry, dietary sources, metabolism, and nutritional significance. Nutr. Rev., 1998; 56(11):317-333.

Brock A, Bieri S, Christen P, Dräger B. Calystegines in wild and cultivated Erythroxylum species. Phytochemistry, 2005; 66(11):12311240 .

Buriol L, Finger D, Schmidt EM, Santos JMT, Rosa MR, Quináia SP, Torres YR. Chemical composition and biological activity of oil propolis extract: an alternative to ethanolic extract. Quim. Nova, 2009; 32(2):296-302.

Chávez JP, Santos ID, Cruz FG, David JM. Flavonoids and triterpene ester derivatives from Erythroxylum leal costae. Phytochemistry, 1996; 41(3):941-943.

Elias ST, Borges GA, Amorim DA, Rêgo DF, Simeoni LA, Silveira D, Fonseca-Bazzo YM, Paula JE, Fagg CW, Barros IMC, Abreu WC, Pinto-Júnior DS, Magalhães PO, Neves FAR, Lofrano-Porto A, Guerra ENS. Radiation induced a supra-additive cytotoxic effect in head and neck carcinoma cell lines when combined with plant extracts from Brazilian Cerrado biome. Clin Oral Invest, 2015; 19(3):637646.

Fonseca APND, Silva GDF, Carvalho JJ, Salazar GCM, Duarte LP, Silva RP, Jorge RM, Tagliati CA, Zani CL, Alves TM. Phytochemical study of the decoct from the leaves of Maytenus truncata Reissek and the evaluation of the antinociceptive, antiedematogenic and antiulcerogenic activities of the decoct extracts. Quim. Nova, 2007; 30(4):842-847.

Fonseca YM, Fernandes C, Monteiro B, Carvalho IM, Gomes SM, Fagg C, Simeoni LA, Silveira D. Determination of rutin in Erythroxylum suberosum extract by liquid chromatography: applicability in standardization of herbs and stability studies. Bol Latinoam Caribe Plant Med Aromat, 2014; 13(2):135-143.

González-Guevara JL, Vélez-Castro H, Gonzalez-Garcia KL, Payo-Hill AL, González-Lavaut JA, Molina-Torres J, Prieto-Gonzalez S. Flavonoid glycosides from Cuban Erythroxylum species. Biochem. Syst. Ecol., 2006; 34(6):539-542.

Grinspoon L, Bakalar JB. Coca and cocaine as medicines: An historical review. J. Ethnopharmacol., 1981; 3(2-3):149-159.

Guarim Neto G, Morais RG. Medicinal plants resources in the Cerrado of Mato Grosso State, Brazil: a review. Acta Bot. Bras., 2003; 17(4):561-584.

Han X, Shen T, Lou H. Dietary polyphenols and their biological significance. Int. J. Mol. Sci., 2007; 8(9):950-988. 
Johnson EL, Schmidt WF, Norman HA. Leaf flavonoids as chemotaxonomic markers for two Erythroxylum taxa. Z. Naturforsch. C. , 1997; 52(9-10):577-585.

Krenna L, Mironb A, Pempa E, Petra U, Koppb B. Flavonoids from Achillea nobilis L. Z. Naturforsch. C., 2003; 58(1-2):11-16.

Kumazawa S, Hamasaka T, Nakayama T. Antioxidant activity of propolis of various geographic origins. Food Chem, 2004; 84(3):329-.

Lee JH, Ku CH, Baek N, Kim SH, Park HW, Kim DK. Phytochemical constituents from Diodia teres. Arch. Pharmacal Res., 2004; 27(1):40-43.

Loiola MIB, Agra MF, Baracho GS, Queiroz RT. Flora of Paraíba, Brazil: Erythroxylaceae Kunth. Acta Bot. Bras., 2007; 21(2):473487.

Luo C, Zou X, Li Y, Sun C, Jiang Y, Wu Z. Determination of flavonoids in propolis-rich functional foods by reversed phase high performance liquid chromatography with diode array detection. Food Chem., 2011; 127(1):314-320.

Macedo TBC, Elias ST, Torres HM, Yamamoto-Silva FP, Silveira D, Magalhães PO, Lofrano-Porto A, Guerra ENS, Silva MAG. Cytotoxic Effect of Erythroxylum suberosum Combined with Radiotherapy in Head and Neck Cancer Cell Lines. Braz Dental J., 2016; 27(1):108-112.

Matthews RS. Artemia salina as a test organism for measuring superoxide-mediated toxicity. Free Radical Biol. Med., 1995; 18(5):919922.

Meyer BN, Ferrigni NR, Putnan JE, Jacobsen LB, Nichols DE, McLaughlin JL. Brine shrimp - a convenient general bioassay for activeplant constituents. Planta Medica, 1982; 45(5):31-34.

Nascimento CJ, Violante IMP, Garcez WS, Pott A, Garcez FR. Biologically active abietane and ent-kaurane diterpenoids and other constituents from Erythroxylum suberosum. Phytochem. Lett., 2012; 5(2):401-406.

Nhiem NX, Van Kiem P, Van Minh C, Ban NK, Cuong NX, Tai BH, Kim YH. Phenylpropanoid glycosides from Heterosmilax erythrantha and their antioxidant activity. Arch. pharmacal Res., 2009; 32(10):1373-1377.

Nogueira MA. 1994. Estudo químico de Mucuna aterrima e da sua atividade nematicida sobre o fitonematóide Meloidogyne incognita raça 3. Universidade Federal de Viçosa, Viçosa.

Oberlies NH, Rogers LL, Martin JM, McLaughlin JL. Cytotoxic and insecticidal constituents of the unripe fruit of Persea americana. Journal of Natural Products, 1998; 61(6):781-785.

Oliveira SL, Tavares JF, Branco MV, Lucena HF, BarbosaFilho JM, Agra MF, Nascimento SC, Aguiar JS, Silva TG, Simone CA, Araujo-Junior JX, Silva MS. Tropane alkaloids from Erythroxylum caatingae Plowman. Chem. Biodiversity, 2011; 8(1):155-165.

Parra AL, Yhebra RS, Sardiñas IG, Buela LI. Comparative study of the assay of Artemia salina L. and the estimate of the medium lethal dose (LD50 value) in mice, to determine oral acute toxicity of plant extracts. Phytomedicine, 2001; 8(5):395-400.

Perez H, Diaz F, Medina JD. Chemical investigation and in vitro antimalarial activity of Tabebuia ochracea ssp. neochrysantha. Int J Pharmacogn, 1997; 35(2):227-231.

Perfeito JP, Santos ML, Lopez KSE, Paula JE, Silveira D. Characterization and biological properties of Pouteria torta extracts: a preliminary study. Braz J Pharmacogn, 2005; 15(3):183-186.

Pietta PG. Flavonoids as antioxidants. J. Nat. Prod., 2000; 63(7):1035-1042.

Plowman T, Hensold N. Names, types, and distribution of neotropical species of Erythroxylum (Erythroxylaceae). Brittonia, 2004; 56(1):1-53.

Prieto P, Pineda M, Aguilar M. Spectrophotometric quantitation of antioxidant capacity through the formation of a phosphomolybdenum complex: specific application to the determination of vitamin E. Anal. Biochem., 1999; 269(2):337-341.
Ribeiro G, Amorim LL, Guimarães SS. Antioxidant Activity and Phytochemical Screening of Extracts of Erythroxylum suberosum A. St.-Hil (Erythroxylaceae). Res J Phytochem, 2015; 9(2):68-78.

Rice-Evans CA, Miller NJ, Paganga G. Structure-antioxidant activity relationships of flavonoids and phenolic acids. Free Radical Biol. Med., 1996; 20(7):933-956.

Silva DA, Costa DA, Silva DF, Souza MFV, Agra MF, Medeiros IA, Barbosa-Filho JM, Braz-Filho R. Glycosyl fl avonoids from Herissantia tiubae (K. Schum) Brizicky (Malvaceae) and preliminary tests of kaempferol 3,7-di-O- $\alpha$-L-rhamnopyranoside. Braz. J. Pharmacog., 2005; 15(1):23-29.

Silverstein RM. 2000. Identificação espectrométrica de compostos orgânicos. LTC Editora,[2000].

Siqueira MJ, Bomm DM, Pereira NFG, Gareez WS, Boaventura M. Activity-guided isolation of constituents of Unonopsis lindmanii - Annonaceae, based on the brine shrimp lethality bioassay. Quim Nova, 1998; 21(5):557-559.

Sousa CMM, Silva HR, Vieira-Jr GM, Ayres MCC, Costa CLS, Araújo DS, Cavalcante LCD, Barros EDS, Araújo PBM, Brandão MS. Total phenolics and antioxidant activity of five medicinal plants. Quim. Nova, 2007; 30(2):351-355.

Subhadra S, Kanacharalapalli VR, Ravindran VK, Parre SK, Chintala S, Thatipally R. Comparative toxicity assessment of three Tephrosia species on Artemia salina and animal cell lines. J Nat Pharm, 2011; 2(3):143.

Velioglu YS, Mazza G, Gao L, Oomah BD. Antioxidant activity and total phenolics in selected fruits, vegetables, and grain products. J. Agric. Food Chem., 1998; 46(10):4113-4117.

Wagner H, Bladt S, Zgainski EM. 1984. Plant drug analysis. Berlim: Springer Verlag.

Wang W, Tian S, Stark RE. Isolation and identification of triglycerides and ester oligomers from partial degradation of potato suberin. J. Agric. Food Chem., 2010; 58(2):1040-1045.

Woisky RG, Salatino A. Analysis of propolis: some parameters and procedures for chemical quality control. J. Apic. Res., 1998; 37(1):99105.

Wolfe KL, Liu RH. Structure- activity relationships of flavonoids in the cellular antioxidant activity assay. J. Agric. Food Chem., 2008; 56(18):8404-8411.

Yang CS, Landau JM, Huang MT, Newmark HL. Inhibition of carcinogenesis by dietary polyphenolic compounds. Annu. Rev. Nutr., 2001; 21(1):381-406.

Zuanazzi JAS, Tremea V, Limberger RP, Sobral M, Henriques AT. Alkaloids of Erythroxylum (Erythroxylaceae) species from Southern Brazil. Biochem. Syst. Ecol., 2001; 29(8):819-825.

\section{How to cite this article:}

Barros IMC, Leite BHM, Leite CFM, Fagg CW, Gomes SM, Resck IS, Fonseca-Bazzo YM, Magalhães PO, Silveira D. Chemical composition and antioxidant activity of extracts from Erythroxylum suberosum A.St. Hil.leaves. J App Pharm Sci, 2017; 7 (03): 088094. 